Portland State University

PDXScholar

1986

\title{
Hemodynamics during pregnancy : a model for cardiac enlargement
}

David James Mendelson

Portland State University

Follow this and additional works at: https://pdxscholar.library.pdx.edu/open_access_etds

Part of the Biology Commons, and the Physiology Commons Let us know how access to this document benefits you.

\section{Recommended Citation}

Mendelson, David James, "Hemodynamics during pregnancy : a model for cardiac enlargement" (1986). Dissertations and Theses. Paper 3707.

https://doi.org/10.15760/etd.5591

This Thesis is brought to you for free and open access. It has been accepted for inclusion in Dissertations and Theses by an authorized administrator of PDXScholar. Please contact us if we can make this document more accessible: pdxscholar@pdx.edu. 
AN ABSTRACT OF THE THESIS OF David James Mendelson for the Master of Sclence In Biology presented July 3, 1986.

Title: Hemodynamics During Pregnancy: A Model for Cardiac Enl argement.

APPROVED BY MEMBERS OF THE THES IS COMMITTEE:

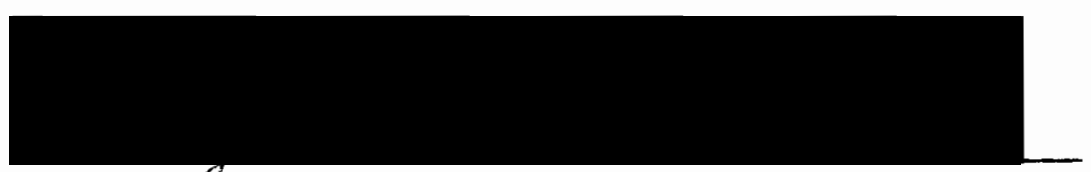

Larry 1/ Crawshaw, Ph.D., Chairman

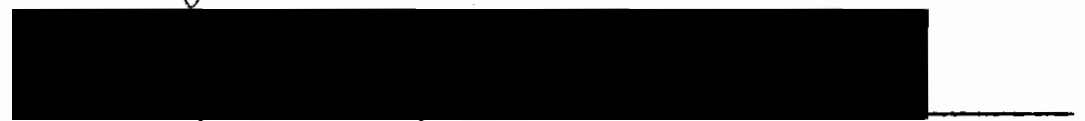

Mary L. /Taylor, Ph.D.

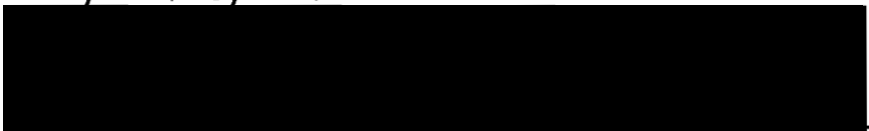

David T. Clark, Ph.D.

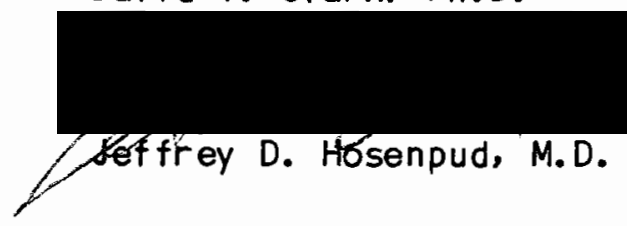

Cardiac output increases by 30-50\% during mammal lan pregnancy. This increase is reflected by elevation in both heart rate and stroke volume. The primary mechanism of Increased stroke volume appears to be cardlac enlargement, rather than increased preload, afterload, or contractllity. Animal studles have shown that enlargement of the heart occurs prior to an increase in uterine blood flow during pregnancy and this type of enlargement can be mimicked by sex sterold administration. 
Systemic vascular resistance greatiy decreases during pregnancy and with sex sterold administration. It has been postulated that systemic vascular resistance may be a signal for heart size changes. This study attempted to chronlcally decrease systemic vascular resistance by administration of an arterlal vasodilator (hydralazine) over a three week perlod to guinea pigs. At the time of study hemodynamics were measured which included, heart rate, arterial pressure, right atrial pressure and cardiac output. In vitro left ventricular pressure volume relationships were also evaluated, as was total plasma volume.

Systemic vascular resistance after 21 days was slightly, though not statistically significantly, decreased $(0.319 \pm 0.071$ vs. $0.360 \pm$ 0.088 Wood Units, $p=$ n.s.). This reflected a slight drop in mean arterlal pressure $(62 \pm 8.6$ vs. $64 \pm 5.1 \mathrm{~mm} \mathrm{Hg}, p=n . s$.$) , as well as$ a slight increase in cardlac output $(241 \pm 34$ vs. $230 \pm 29 \mathrm{ml} / \mathrm{mln}, p=$ n.s.). There was no detectable change in left ventricular chamber size as assessed by left ventricular pressure volume relationships.

The difficulties of chronic pharmacologic systemic vasodilation of the normal circulation are discussed with reference to the varlety of compensatory mechanisms that are brought into play. 
HEMODYNAMICS DURING PREGNANCY: A MODEL FOR CARDIAC ENLARGEMENT

by

DAVID JAMES MENDELSON

A thesis submitted in partial fulfilliment of the requirements for the degree of

\author{
MASTER OF SCIENCE \\ in \\ BIOLOGY
}

Portland State University

1986 
TO THE OFFICE OF GRADUATE STUDIES AND RESEARCH:

The members of the Committee approve the thesls of David James Mendelson presented on July 3, 1986.

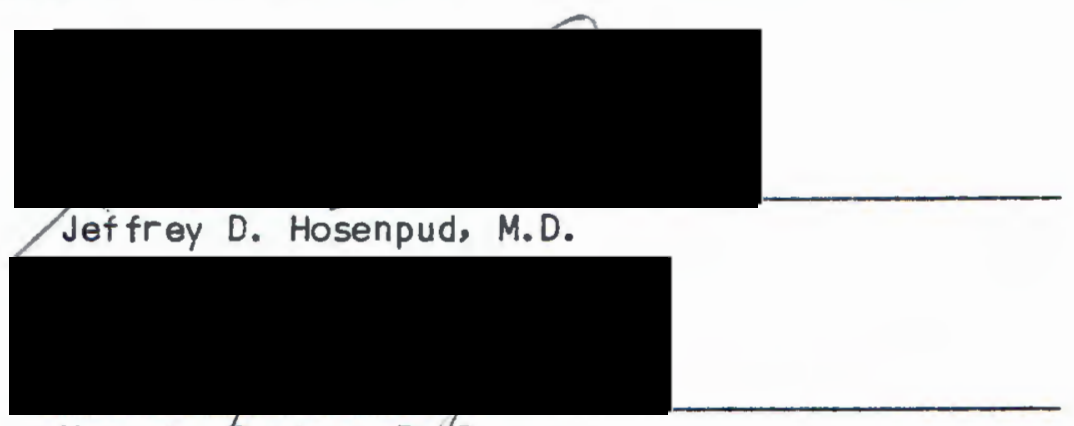

Mary L. Taylor, Ph.D.

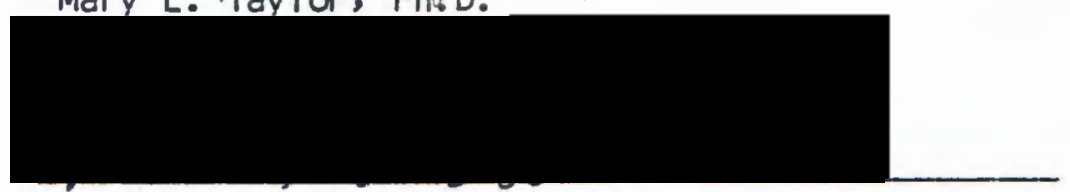

David T. Clark, Ph.D.

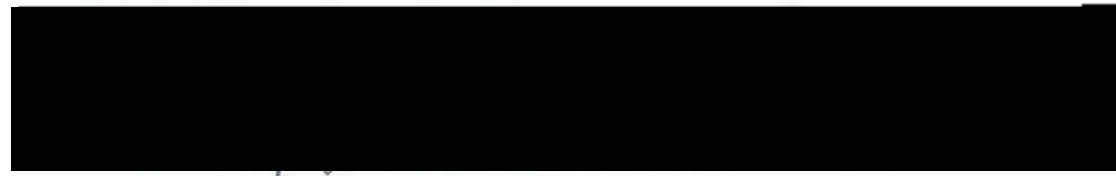

Larry 1. frawshaw, Ph.D.

APPROVED:

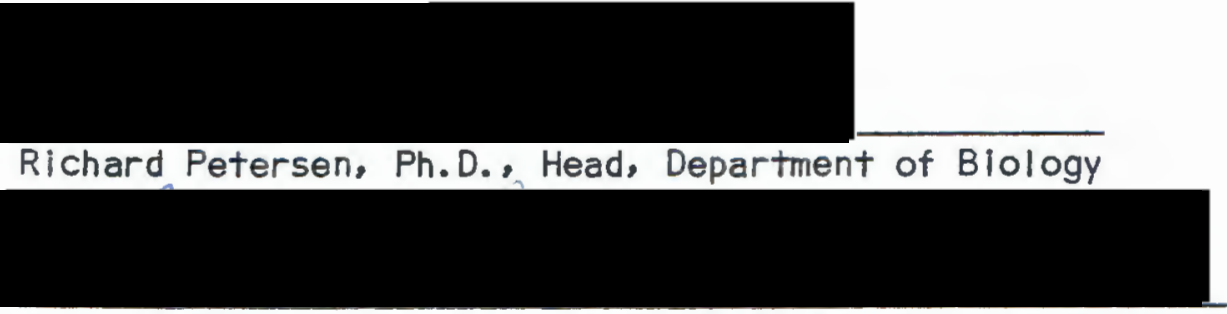

Bernard Ross, Ph.D., Dean of Graduate Studles and Research 


\section{ACKNOWLEDGEMENTS}

I would like to express my appreciation to all of the people who contrlbuted to the completion of this study. Dr. Metcalte kindly allowed me to do my research in the Heart Research Laboratory at OHSU. The entire Heart Research Laboratory staff added support and made me feel at home during my two years of research there. Specifically, I wish to acknowledge Cathy Ramsey and J. Eugene Welch for their laboratory assistance, Jane Lee for her assistance with animal surgery and data acquisition, and Jackle Niemi for typing the drafts and final copy of this thesis. I would especially like to express my gratitude to Dr. Larry Crawshaw and the Portland State University Department of Biology, and to Dr. Jeffrey Hosenpud of OHSU for their cooperative efforts in making this research program possible. Finally, this study was supported in part by a Program Project Grant from the National Institutes of Health, HD 10034. 


\section{TABLE OF CONTENTS}

PAGE

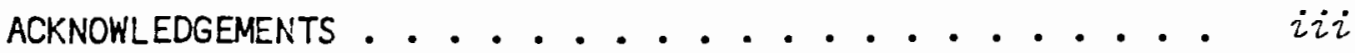

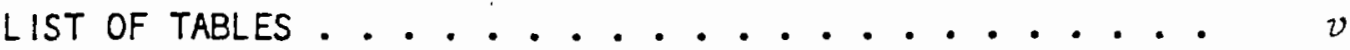

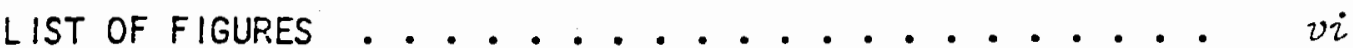

REV IEW OF THE LITERATURE . . . . . . . . . . . . 1

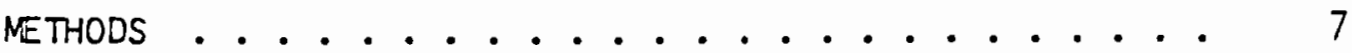

Cholce of Experimental Animal ........ 7

Choice of Pharmacologlc Drug........ . 7

Determination of Drug Dose ........ . 7

Animal Preparation............. 8

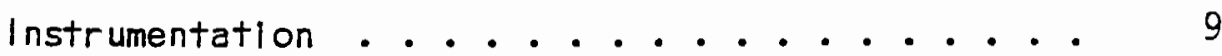

study ................. 10

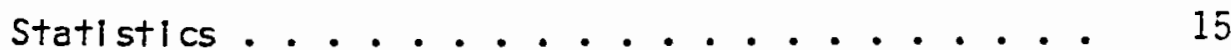

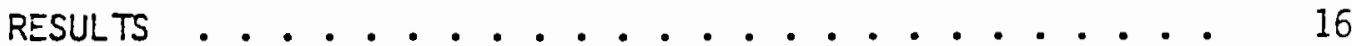

Dose Determination Study.......... 16

Chronic Dosing Study............ 16

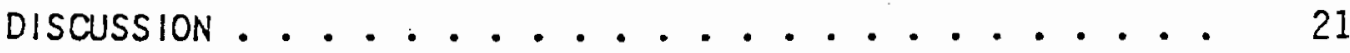

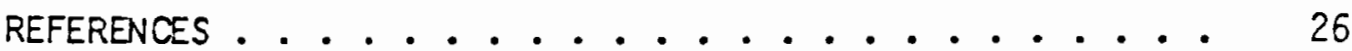




\section{LIST OF TABLES}

TABLE

PAGE

I. Table of Changes ............. 5

II. (untltled)................ 16

III. Hemodynamic Data .............. 18 


\section{LIST OF FIGURES}

FIGURE

PAGE

1. Pressure Tracings and Heart Rate ........ 11

2. Thermodilution Curve . . . . . . . . 13

3. Cardlac Output vs. Aortlc Flow ........ 13

4. Apparatus Used to Isolate Left Ventricle During Pressure-Volume Measurements ....... 14

5. Pressure-Volume Curve ........... 15

6. Prelliminary Dosing Data .......... 17

7. Left Ventricular Pressure-Vol ume Data . . . 20 


\section{REV IEW OF THE LITERATURE}

During pregnancy cardlac output increases by $30-50 \%$ in all mammals studied to date, including humans (1-6). The time course of th is increase has been a topic of investigation in the past, but most authorities report peak values by the second trimester $(1,2)$. The determinants of cardiac output, stroke volume and heart rate, both increase during pregnancy $(1,2)$. However, mechanisms responsible for these changes have been inadequately explained. Recent studies from our laboratory in the Pygmy goat suggest that the heart rate increase may be both mediated autonomically as well as medlated through a change in intrinsic sinus node automaticity (4). The increase in stroke volume is also not agreed upon. The potential mechanisms by which stroke volume could be increased are preload, afterload, and contractility.

Many studies have shown a 40-50\% increase in blood volume during pregnancy $(2,7,8,9)$. This would seem to suggest that increased preload (sarcomere length at the end of diastole) may be important to increased cardiac output. However, infusion of whole blood or dextran in amounts sufficlent to double left ventricular filling pressure have shown only small changes in left ventricular dimensions, stroke volume, and cardiac output $(10,11)$. This evidence suggests that an increase in preload from increased blood volume contributes little to increased stroke volume during pregnancy. Moreover, studies in women (12) and pregnant guinea pigs (13) have falled to show increased filling pressures. 
Left ventricular function has been assessed by noninvasive measurements of contractility such as systolic time intervals and echocardlographic ejection phase indlces. Results from systolic time interval studies have not been consistent. In one study Rubler et al. reported that the isometric contraction period was shorter during the third trimester of pregnancy than postpartum and concluded that left ventricular contractllity was greater during pregnancy (14). Burg et al. al so measured systoll c time intervals and reported a prolonged pre-ejection perlod and a shortened left ventricular ejection time, suggesting impaired left ventricular performance (15). A recent serlal echocardiographic study has shown that left ventricular performance is not changed during pregnancy (16). In addition, data suggest that calculations by systolic time intervals are influenced by maternai position $(15,16)$. However, since these methods are sensitive to changes in preload and afterload, conclusions about ventricular function during pregnancy need qualification (17).

Changes in afterload are also difflcult to evaluate. Afterload is probably best approximated by wall stress of the ventricle. The parameters of left ventricular wall stress are left ventricular chamber size and wall thickness (La Place), and systemic vascular resistance (18). Other factors also include rate of ventricular emptying and aortic impedance (18). During pregnancy the left ventricular chamber size to wall thickness ratio increases which would tend to increase afterload. However, systemic vascular resistance and aortic Impedance are reduced as is left ventricular ejection time (16), factors all tending to reduce afterload. 
A fourth determinant of stroke volume, ventrlcular enlargement, was shown as early as 1825 to occur in pregnancy (19). With a larger heart, none of the traditional determinants of stroke volume need play a role. Experiments of near term guinea pig pregnancy have shown that the left ventricle is remodeled so that its volume is larger at any glven fllling pressure (13). Enlargement of the heart would have the advantage of increasing stroke volume without changing filling pressure and would not change the short term operating mechanisms for stroke volume so that preload, contractllity, and afterload could stlll change in accordance to cardlovascular demands.

Morphologic changes of the heart are not unlque to pregnancy. Increased heart size and mass are observed in response to vigorous physical activity. In an echocardiographic study of 56 tralned athletes, Morganroth et al. compared left ventricular end diastolic pressure (LVEDP) to wall thickness ratios in both isotonic and isometric exercise groups to control groups (20). Morganroth and his colleagues also calculated heart mass. Results showed that the isotonic exercise group increased LVEDP and heart mass but not wall thickness compared to controls. Athletes involved in isometric exercise increased wall thickness and mass but left ventricular end diastolic volume (LVEDV) did not change significantly. In a study of chronic volume overload caused by arteriovenous $(A-V)$ fistula on dogs, Ross showed a thicker, more massive heart developed although contractility did not change. When the fistula was removed, hearts returned to normal states (21). The implications of these results are two fold. The heart responds chronically to increased cardiovascular 
demands by morphologlc changes. Also the morphologic changes are demand specific.

The mechanisms for cardiac enlargement during pregnancy have not been adequately explained. One of the first hypotheses for enlargement during pregnancy was presented by Burwell in 1938 (22). He proposed that the placenta acts as an A-V fistula. Blood flow through the placenta is parallel to maternal circulation; thus, blood pressure is lowered and other circulatory changes may be a result of this. Some hemodynamic changes seen in pregnancy, such as increased heart rate and cardiac output, and decreased $A-V$ oxygen difference, are also characteristics of an A-V fistula. Although this concept was widely accepted for many years, there are problems with this interpretation. The cardiac eniargement produced by experimental A-V fistula is dissimilar to that seen in pregnancy as filling pressures are markedly elevated $(21,23)$. Furthermore, Hart et al have show'n that blood volume, cardiac output, stroke volume and heart size are all increased during the first trimester of guinea plg pregnancy, well before a change in uterine blood flow takes place (13). The increase in left ventricular chamber size was associated with an increase in the ratio of left ventricular chamber radius to wall thickness, a morphologic change previousiy descrlbed as being associated with pregnancy (16). Table I compares the cardlac enlargement associated with pregnancy to other known conditions associated with cardiac enlargement. As can be seen, the cardiac enlargement associated with pregnancy appears to be a unique physiologic adaptation. 
TABLE I. TABLE OF CHANGES

\begin{tabular}{lccccc}
\hline & Stroke-Vol. & LVEDP & LVED Diam. & $\begin{array}{c}\text { LV Wall } \\
\text { Thickness }\end{array}$ & $\begin{array}{c}\text { Radius-Wall } \\
\text { Thickness }\end{array}$ \\
\hline Pregnancy & + & -- & + &.- & + \\
Expt. AV Fistula & + & + & + & $?$ & $?$ \\
Isotonic Training & + & $\cdots-$ & + & + & $\cdots$ \\
Isometric Training & --- & $-\cdots$ & --- & $+\uparrow$ & ++ \\
\hline
\end{tabular}

Hormones have long been known to be powerful mediators of control mechanisms. Estrogen and progesterone levels are elevated in pregnancy. The corpus I uteum and the placenta both contribute to this increase. In 1955, Brehm suggested that cardiac output may be regulated by peripheral resistance and that maternal hormones were a fundamental cause of cardlac varlation. Exogenous estrogen administration was studied by Parer and Veland in ewes (24). They showed that cardlac output and heart rate were elevated and mean arterial pressure and peripheral resistance decreased. These changes were similar to those seen in pregnant ewes (25). Other studies of women taking oral contraceptives have also demonstrated increased cardlac output, stroke volume, blood volume and blood pressure $(26,27)$. In one study, progesterone and estrogen were administered separately (28). Cardiovascular changes similar to those in pregnancy were seen only in those patients given estrogen. Studies in our laboratory on guinea pigs chronically receiving progesterone and/or estrogen confirm these observations. Estrogen treated animals had 
significant increases in cardlac output, stroke volume, blood volume and left ventricular chamber slze compared to controls, essentially mimicking the hemodynamic changes seen In pregnancy. Several studles of hormone receptors have shown that the heart and major arterles have estrogen and androgen receptors, suggesting that the central cardiovascular system may be a target organ for these hormones $(29,30,31,32)$.

A fall in systemic vascular resistance appears to be common to most, If not all, instances where cardlac enlargement occurs (pregnancy, estrogen adminlstration, $A-V$ fistula). To test the hypothesis that systemic vascular resistance has a primary role in determining left ventricular chamber size, hydralazine (an arterlal dilator) was administered chronically to guinea pigs. 


\section{METHODS}

Choice of Experimental Animal

Male guinea pigs were chosen as the experimental model for this study. Substantial literature exists using guinea pigs as models for cardiovascular physiologic investigation $(3,13,33,34,35,36,37)$.

Males were used to avold any estrus related hormone varlabllity. The guinea pig is relatively small and easy to handle, but large enough for thorough hemodynamic investigation. In addition, the Heart Research Laboratory has had extensive experience with this animal $(13,38,39)$. The above reasons made the guinea pig an attractive model for the study of maternal cardiovascular physiology.

\section{Choice of Pharmacologic Drug}

Hydralazine was chosen as the drug to reduce vascular resistance primarlly because of its mechanism of action: relaxation of arterlal smooth muscle, particularly at the arterioles (40). It has no direct effects on the autonomic nervous system (40) nor any known direct effects on the cardiac muscle. Chronic administration of hydralazine has been used in rodents with the appropriate fall in systemic vascular resistance (41). Finally, the extensive use of hydralazine in treatment of hypertension and congestive heart failure clinically adds interest to experimental results $(42,43)$.

\section{Determination of Drug Dose}

Dose testing was performed using two separate protocols. The first group was dosed subcutaneously by implantation of hydralazine 
tablets (hydralazine with cholesterol, lactose, and methylcellulose). These animals were first anesthetized with ketamine/xylazine (see Instrumentation). An Incision in the neck was made and the carotid artery was isolated and cannulated with a polyvinyl catheter (see (nstrumentation). The catheter was tunneled to the ventral part of the neck, filled with heparin (500 units/ml) and capped. This catheter allowed blood pressure, and heart rate measurements to be made. Baseline welghts, blood pressure, and heart rates were taken and compared with post-implantation measurements every other day. Measurements were continued until blood pressures returned to basel ine.

The second protocol differed only in the form of hydralazine administration. These animals were dosed orally via their drinking water. Powdered hydralazine hydrochloride (apresoline: 1hydrazinophthalazine) was used. Anesthesla, surgery, dose levels and daily measurements were conducted exactly as in Protocol 1.

Both protocols reduced arterial blood pressure by about the same amount and for the same duration (see Results). The oral dosing method was chosen for this study for two main reasons: it was less traumatic for the animals, and it was much more convenient to administer.

\section{Animal Preparation}

Thirty male guinea pigs between the weights of 700 and 1000 grams were matched according to weight and strain (Duncan-Hartley or Topeka) and placed into two groups: treated and control. The animals were purchased from and housed in the Oregon Health Sciences 
University Department of Animal Care. The housing included continuous access to food and water, a 12-hour IIght cycle, and a constant room temperature of 21 degrees centigrade. The treated group was given hydralazine in their drinking water daily for three weeks. The beginning dose was $5 \mathrm{mg} / \mathrm{kg} /$ day. At the beginning of weeks 2 and 3 the dose was increased by an additional $5 \mathrm{mg} / \mathrm{kg} /$ day. During the three weeks, animal water consumption was randomly measured to verify that dosing was consistent (evaporation was accounted for). At the end of three weeks animals were instrumented and studied.

\section{Instrumentation}

On the appropriate day, animals were given an intramuscular injection of ketamine $(25 \mathrm{mg} / \mathrm{kg})$ and $x y / a z i n e(0.15 \mathrm{mg} / \mathrm{kg})$ to provide a surgical level of anesthesia (44). Ketamine acts as a dissociative anesthetic and $x y l a z i n e$ as a non-narcotic sedative and muscle relaxant. The combination of these two drugs is often used to provide anesthesia during invasive instrumentation. Cardiovascular effects of this combination have been investigated in the guinea pig (44). Adequate anesthesia is provided for approximately 90 minutes and by 3 hours post injection hemodynamics have returned to baseline. This time period provides ample time to instrument the animals and al low them to recover so that the studies can be performed in one day without alterling hemodynamic measurements. Surgery was performed under clean but not sterlle conditions. A transverse ventral incision was made in the neck. The jugular vein and carotid artery were isolated and cleaned of fat and connective tissue. A thermodilution probe (Edwards Lab 1.5F) was Inserted into the carotid artery and 
advanced retrograde $4 \mathrm{~cm}$ into the ascending aorta. A second inclsion was made in the right groin and the superficial saphenous artery was isolated. A polyvinyl catheter $(0.9 \mathrm{~mm} 0.0 ., 0.5 \mathrm{~mm}$ 1.D.) was inserted and advanced $6 \mathrm{~cm}$ retrograde into the abdominal aorta. Placement of catheters was verifled by pressure monitoring. Catheters were then tunneled subcutaneously to the dorsal part of the neck, fllled wlth heparin solution (150 units/ml), capped and secured until the time of study. AnImals were placed in a large recovery cage and allowed free access to food and water.

\section{Study}

Animals were al lowed to recover for 6 to 7 hours post anesthesia injection. At this time animals were placed in a study cage which permitted little movement. The animals were left in the darkened, quiet room for a 30-minute acclimation period.

Resting values for systolic, diastolic, and mean blood pressures, as well as respiratory and heart rates were measured simultaneously using Statham P-23 Gb pressure transducers zeroed to mid-chest and displayed on a Gllison 5/6 stripchart recorder. A typical pressure recording is shown in Figure 1.

Cardlac output was determined using the thermodilution method. Thermodil ution cardlac outputs were performed as follows: 0.4 milliliters of room temperature saline were injected as a bolus into the right atrial catheter. Temperature change was reglstered by the thermistor probe, and cardiac output was calculated with a dedicated thermodil ution cardlac output computer (Edwards Laboratorles Model 9520A) using the formula: 


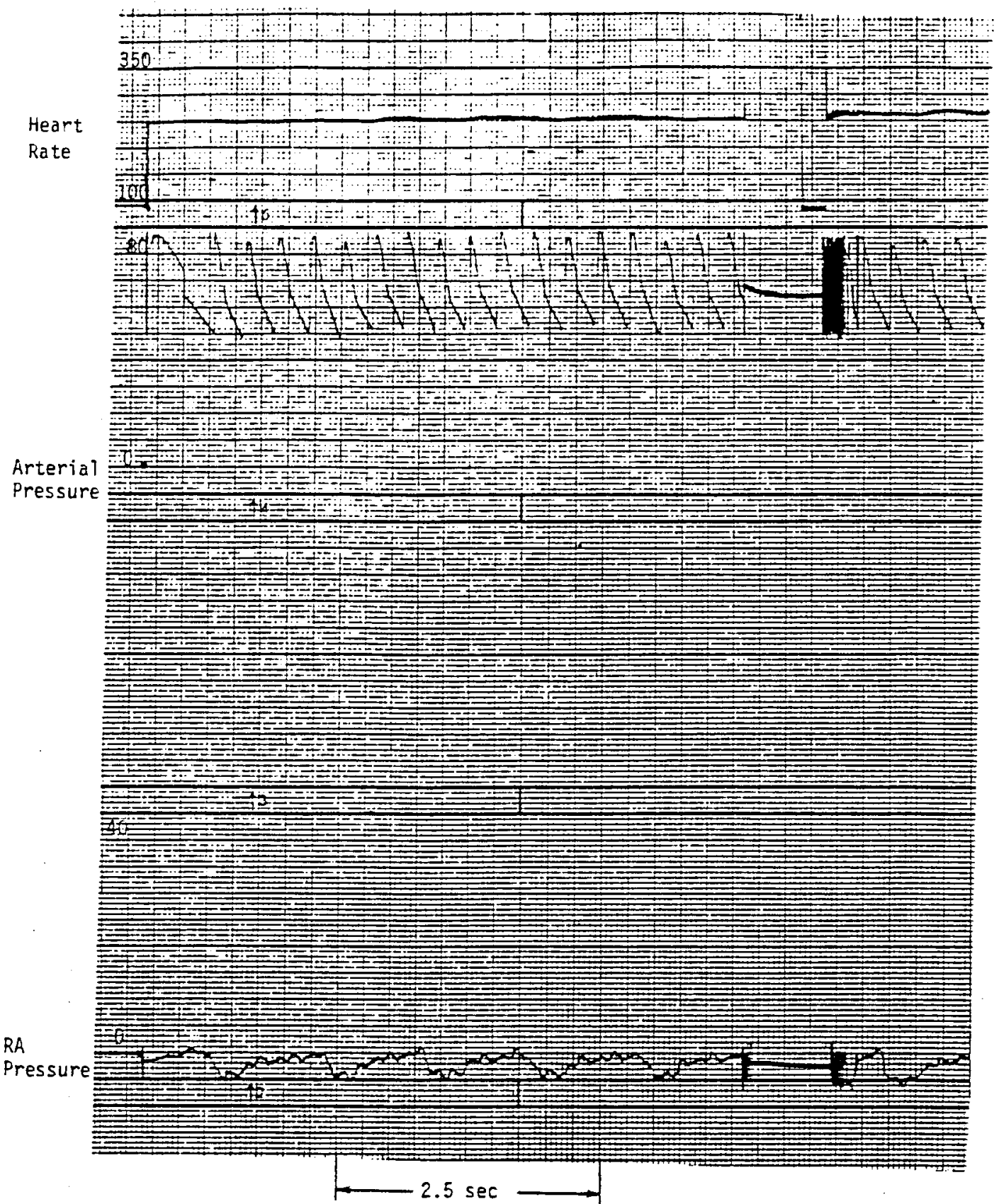

FIGURE I 


$$
\begin{aligned}
C O= & \{\rho \text { Co (injectate) }(60) \quad C+V i \quad(T b-T i)\} / \\
& \left\{\rho C o \text { (b/ood) } f_{0}^{\tau} \text { Tb (t) dt }+c\right\}
\end{aligned}
$$

where $\mathrm{CO}=$ cardiac output, $\rho \mathrm{Co}=$ density $\times$ specific heat of the injectate or blood, $\mathrm{Vi}=$ injectate vol ume, $\mathrm{Ct}=$ dead space correction factor, $\mathrm{Tb}=$ blood temperature, $\mathrm{Tl}=$ injectate temperature, $\tau=30 \%$ of peak value of descending limb of thermodilution curve, $\int_{0}^{\tau} \mathrm{Tb}(t) \mathrm{dt}=$ area under the thermodilution curve to $\tau$, and $c=$ remaining area under the thermodil ution curve (45). Based upon the volume of the injectate, the dead space and calculated heat loss using the right atrial catheter, a computation constant $(1.08 \mathrm{Ct}(60) \mathrm{Vi})$ of 0.20 was utilized. A typical thermodilution curve is shown in Figure 2. Valldation of this method of cardiac output determination in guinea pigs has been performed in our laboratory by comparing thermodil ution cardiac output to aortic flow as measured by callibrated electromagnetic flow probe. The results are shown in figure 3 . The correlation between aortic flow and thermodilution was $0.88(p<0.05)$.

The hematocrit was also determined using packed ceil volumes of samples centrifuged for 5 minutes in standard capillary tubes. Blood volume was determined by dye dilution (34). Briefly, $0.40 \mathrm{ml}$ of an Evans blue dye (T-1824) standard solution was infused into the right atrlal catheter, followed by $2 \mathrm{ml}$ of saline to ensure complete delivery. After 5 minutes, a $4 \mathrm{ml}$ sample of blood was removed from the arterial catheter. The sample was centrifuged and the plasma 


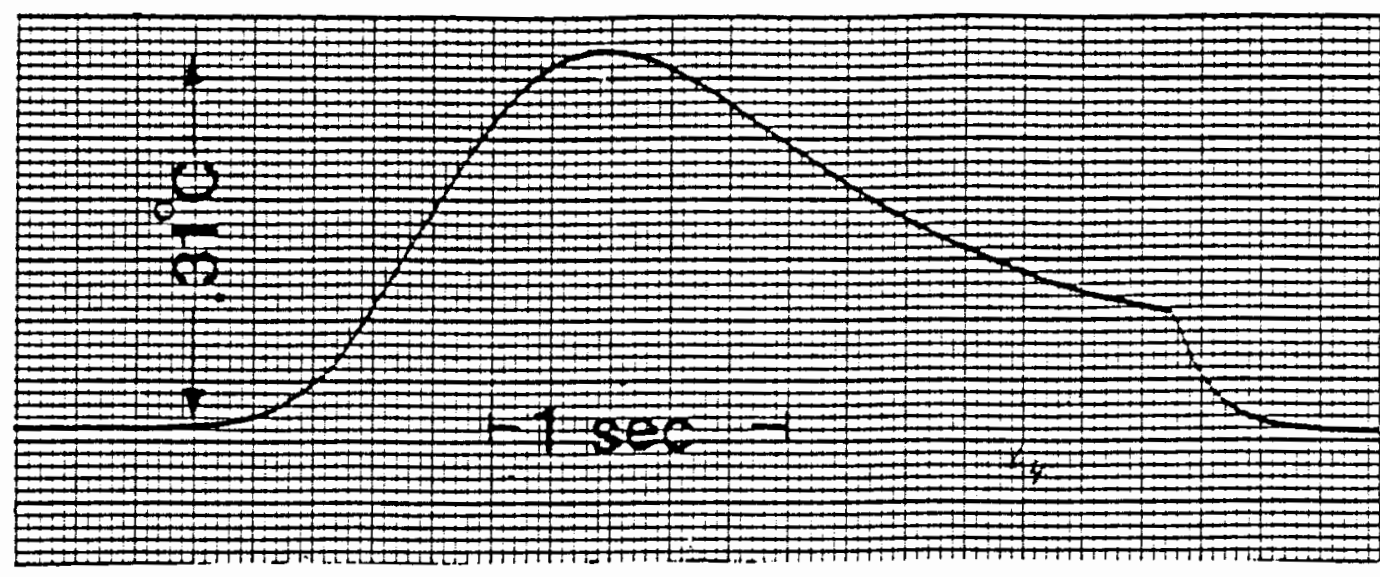

FIGURE 2

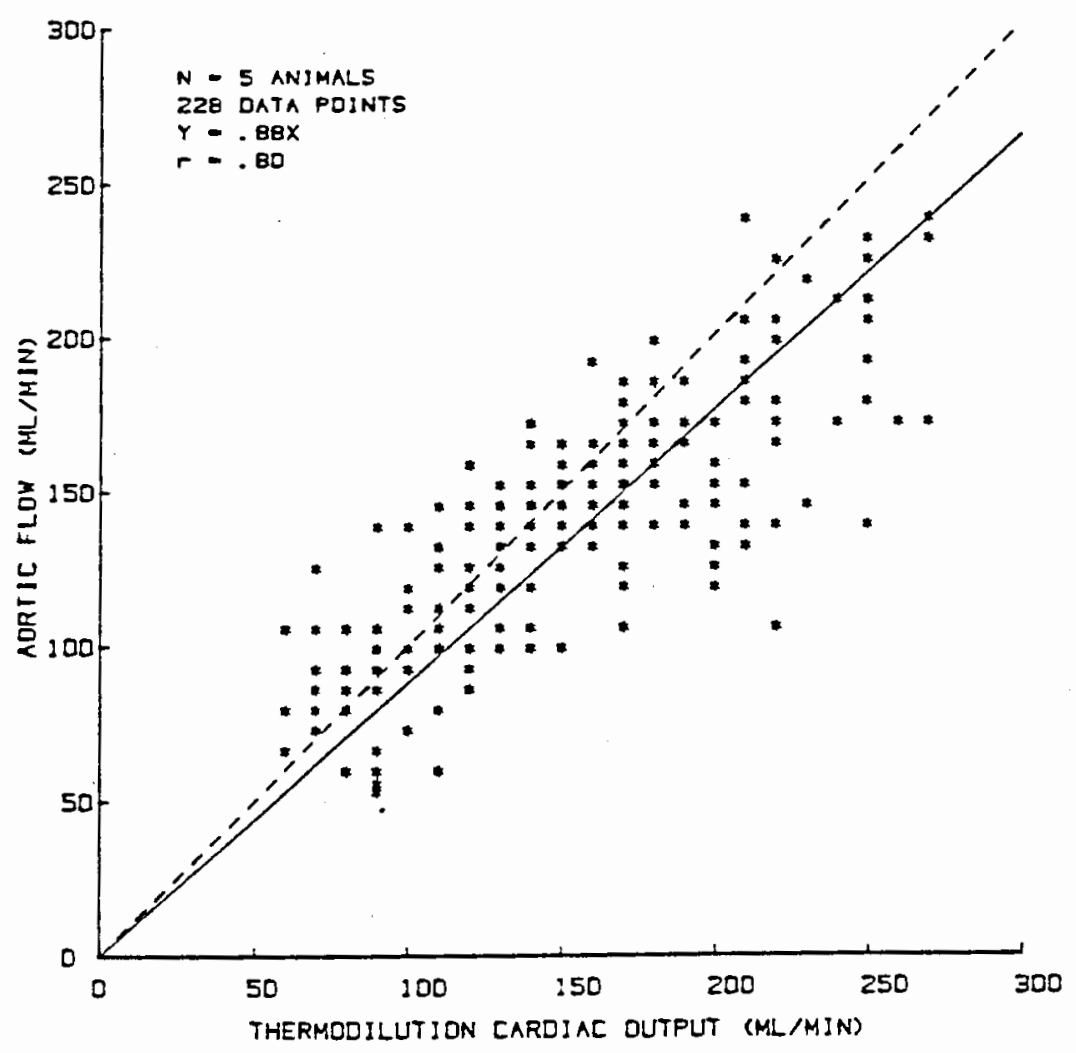

FIGURE 3 
removed. Dye concentration was measured with a spectrophotometer (Coleman Junior 11 model $6 / 20$ ) at a wavelength of $620 \mathrm{~nm}$. The spectrophotometer was zeroed with a blank plasma reference (taken before dye infusion) from the same animal. Plasma volume was calculated from a known standard curve.

Following in vivo studies, in vitro left ventricular pressurevoi ume date were generated as follows. Animals were anesthetized with $20 \mathrm{mig} 3 \mathrm{orta}(\mathbb{R}$ and then lethally injected with $1 \mathrm{ml}$ of saturated potasslum chloride intravenously which resulted in dlastolic cardiac arrest. The chest was then opened and the heart was removed. The right ventricle and atrium were dissected away. A small incislon was made in the left atrial appendage and a double lumen grooved plug was inserted to the level of the mitral annuli's (Figure 4). A sllk suture was tied tightly around the atrial ventricular groove. With the left ventricle isolated and secured the plug was connected to a $10 \mathrm{ml}$ syringe on a Harvard infusion/withdrawal pump and to a Statham p23 Gb pressure transducer zeroed at mid-ventricular level. The system was

Figure 4. Apparatus used to isolate left ventricle during pressure-volume measurements.

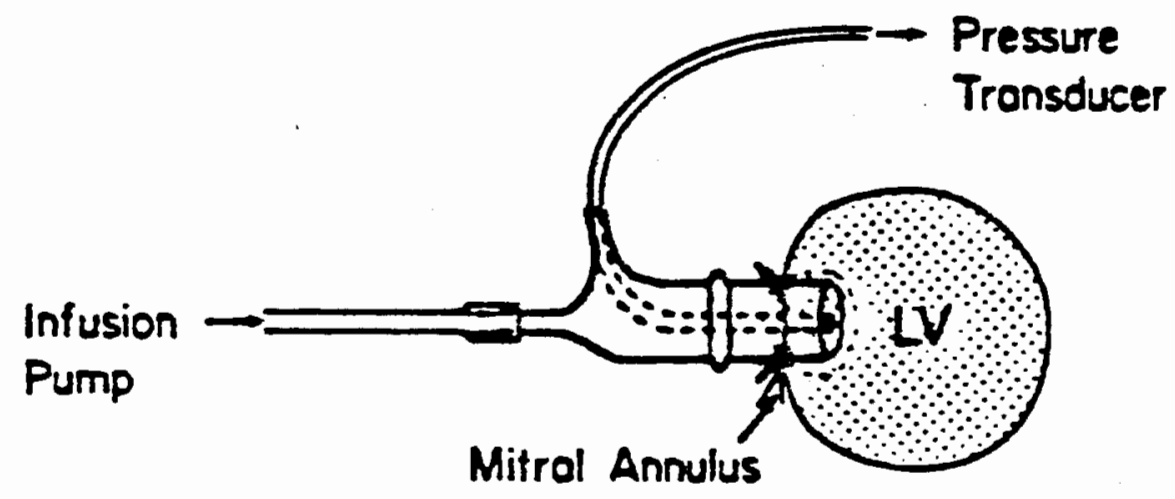


fllled with sallne and all alr bubbles flushed out. The left ventricle with plug inserted was suspended in a saline-fllled dish. Intraventricular pressure was measured continuously from zero pressure and volume during constant infusion for 5 to 10 seconds at a call ibrated rate. The pressure was al lowed to reach only $30 \mathrm{~mm} \mathrm{Hg}$ to avold stretching. A typical pressure-volume curve is shown in Figure 5. After three successful curves had been recorded, the left ventricle was removed from the plug, cut open, blotted and weighed.

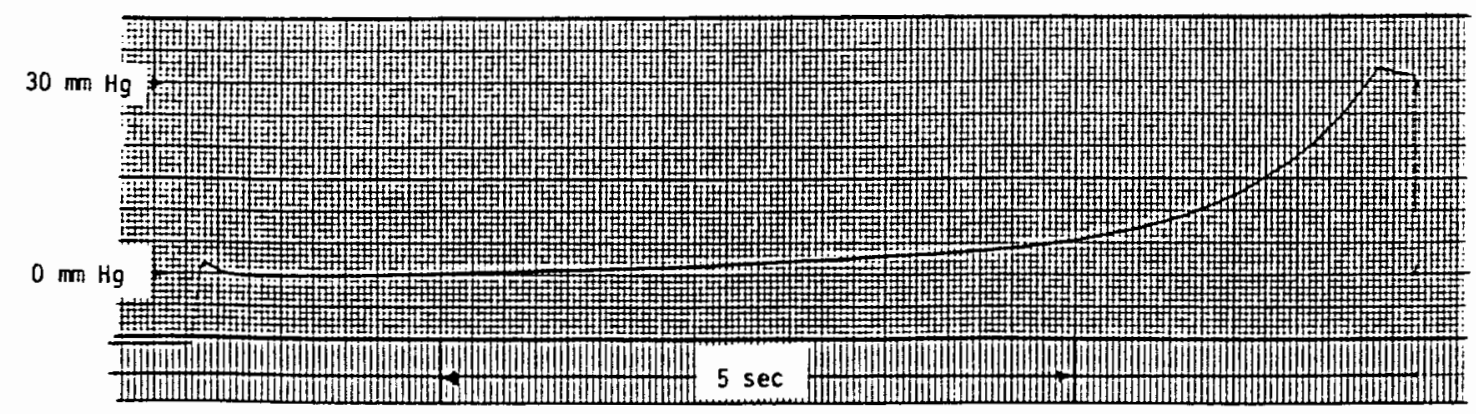

FIGURE 5

Utllizing the calibrated infusion rate, pressure time recordings were converted to pressure-volume values. Values were taken at 0.05 $\mathrm{ml}$ increments and from 2 to $24 \mathrm{~mm} \mathrm{Hg}$, and were compared between groups. All pressure-volume studles were completed with in 15 minutes of $\mathrm{KCl}$ injection. We have noted rigor (a leftward shift in the pressure-volume curve) in the gulnea pig in no less than 40 minutes.

\section{Statisties}

Student's t test for non-paired data was used for this Investigation. Significance was considered present if $p<0.05$. 


\section{RESULTS}

Dose Determination Study

Figure 6 shows arterial pressures over time for the animals dosed subcutaneously and orally with hydralazine. Arterial pressures initially were $15 \%$ below control and returned to control val ues by day 14.

Chronic Desing Study

Fifteen animals were randomized to each stuoy group. Table II shows body and left ventricular weights, total plasma volume, and hematocrits. All animals gained welght during the study as would be expected of healthy, growing animals. Study groups were well matched as seen by simllar mean body welghts.

\section{TABLE II}

\begin{tabular}{lcc}
\hline & Control & Treated \\
\hline Weight $(\mathrm{kg})$ & $0.899 \pm 0.805$ & $0.903 \pm 0.806$ \\
LV weight $(\mathrm{g})$ & $1.355 \pm 0.166$ & $1.328 \pm 0.153$ \\
Plasma volume $(\mathrm{m})$ & $40.7 \pm 5.0$ & $43.4 \pm 5.5$ \\
Hematocrit & $39.5 \pm 2.9$ & $39.4 \pm 2.8$ \\
\hline
\end{tabular}

Values are mean \pm S.D.; $n=15$

Table III displays the hemodynamic data for both groups. Systollic and diastolic pressures were slightly lower in the treated animals but the differences were not significant. Right atrial pressure was not different between groups. 


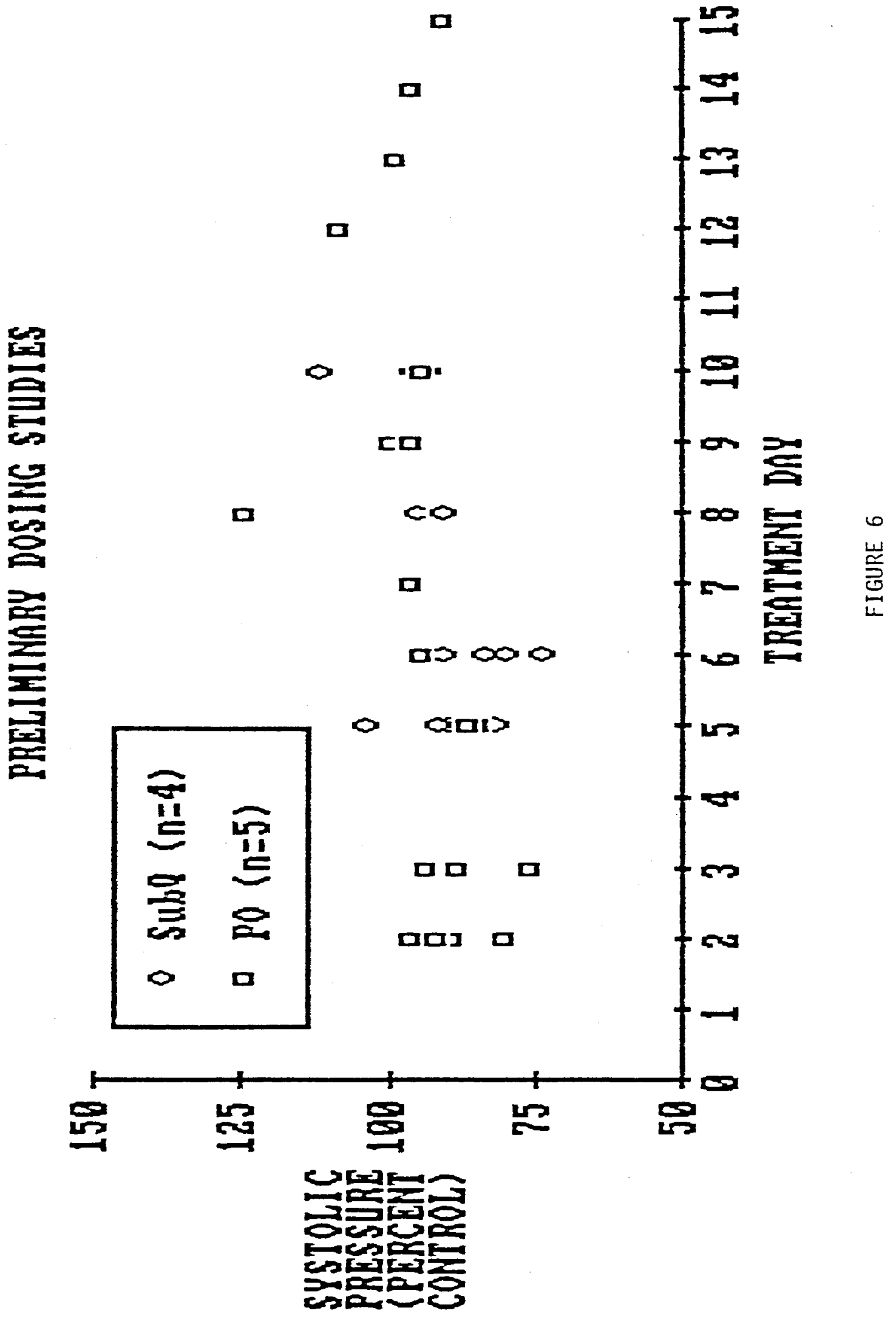


TABLE III

Control

Treated

Heart rate (beats/min)

$246 \pm 33$

$249 \pm 27$

Systolic pressure $(\mathrm{mm} \mathrm{Hg})$

$83 \pm 8$

$79 \pm 10$

Diastolic pressure $(\mathrm{mm} \mathrm{Hg})$

$51 \pm 4$

$51 \pm 7$

Mean pressure $(\mathrm{mm} \mathrm{Hg})$

$$
64 \pm 5
$$

$62 \pm 9$

Right atrial pressure $(\mathrm{mm} \mathrm{Hg})$

$0.05 \pm 0.70$

$0.93 \pm 1.40$

Cardiac index $(\mathrm{ml} / \mathrm{min} / \mathrm{kg})$

$230 \pm 28$

$241 \pm 35$

Stroke volume index $(\mathrm{ml} / \mathrm{kg})$

$$
0.93 \pm 0.13
$$

$0.97 \pm 0.15$

Systemic vascular resistance

$0.360 \pm 0.088$

$0.319 \pm 0.071$

LV volume at various pressures:

$\begin{array}{lll}2 \mathrm{~mm} \mathrm{Hg} & 0.513 \pm 0.131 & 0.559 \pm 0.127 \\ 4 \mathrm{~mm} \mathrm{Hg} & 0.769 \pm 0.138 & 0.796 \pm 0.105 \\ 6 \mathrm{~mm} \mathrm{Hg} & 0.915 \pm 0.141 & 0.930 \pm 0.093 \\ 8 \mathrm{~mm} \mathrm{Hg} & 0.998 \pm 0.147 & 1.019 \pm 0.095 \\ 10 \mathrm{~mm} \mathrm{Hg} & 1.058 \pm 0.149 & 1.075 \pm 0.099 \\ 12 \mathrm{~mm} \mathrm{Hg} & 1.020 \pm 0.301 & 1.121 \pm 0.105 \\ 14 \mathrm{~mm} \mathrm{Hg} & 1.142 \pm 0.156 & 1.157 \pm 0.108\end{array}$

Values are mean \pm S.D.; $n=15$ 
Cardiac output was normalized to body welght so that different slzed animals could be more accurately compared. Cardlac "Index" (cardlac output/body welght) was slightly higher in the treated group and systemic vascular resistance lower, but the differences were not significant. Stroke volumes were the same for both groups.

Plasma volume was slightly elevated in the treated group but not statistically different. Hematocrit was the same for both groups.

Left ventricular welghts were the same for both groups. Left ventricular size at any given pressure was slightly larger for the treated group (Figure 7), but again, not slgnificant. 


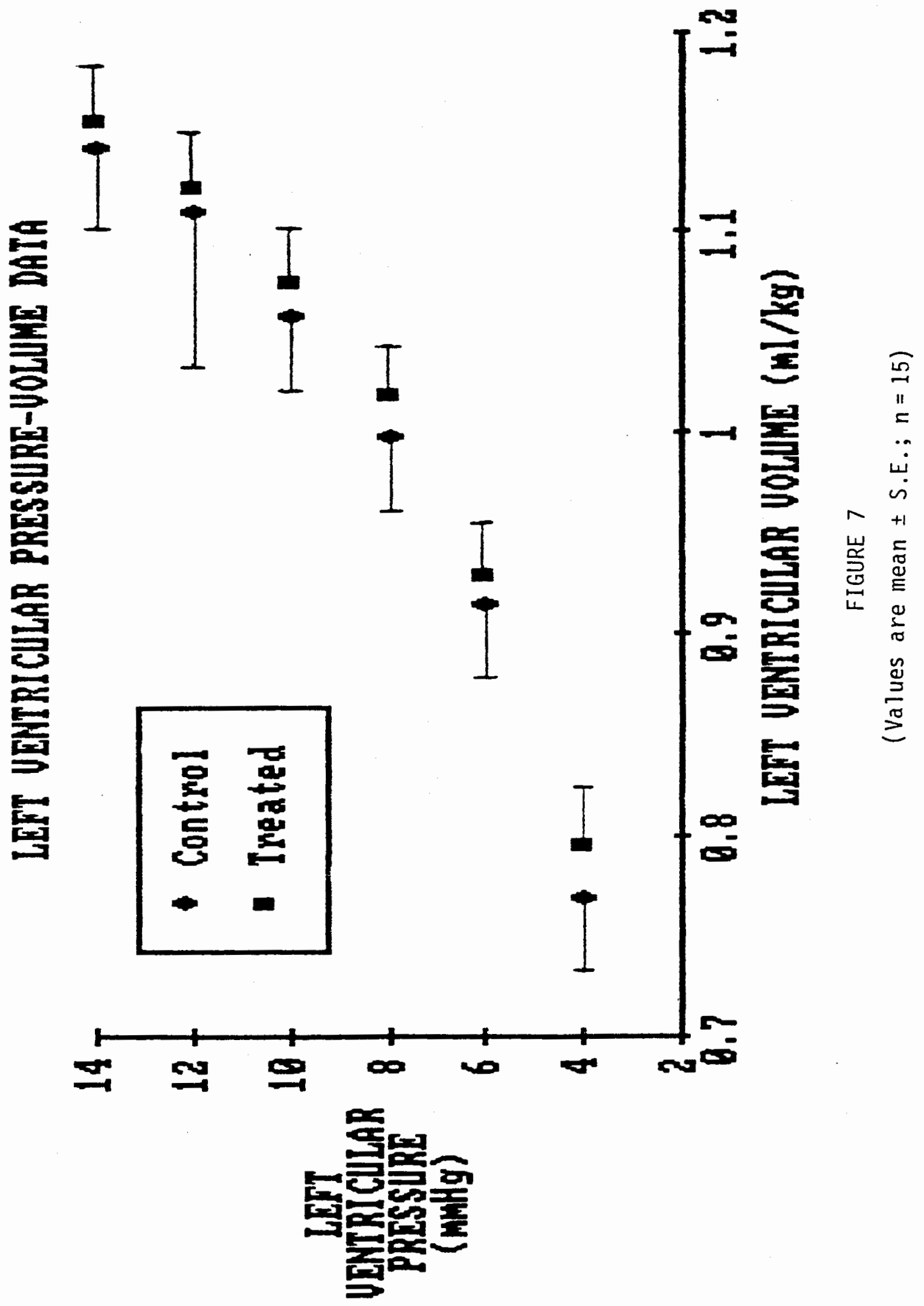




\section{DISCUSSION}

This study demonstrates the difficulties assoclated in attempting to change hemodynamic homeostasis chronically. Despite large doses of hydralazine given orally, systemic vascular resistance was only mildly affected at three weeks. Along with the small decrease in systemic vascular resistance, a small decrease in blood pressure was observed, as well as a slight rise in cardiac index and stroke volume index. Also, left ventricular chamber size tended to be larger at any given filling pressure for the hydralazine treated animals. Although no changes listed above were statistically significant, the direction of the changes is similar to that seen in pregnancy or sex sterold administration $(12,13)$.

Hydralazine was administered orally. The decision to use hydralazine was based on several criterla: 1) hydralazine is easy to administer when dissolved in water; 2) hydralazine is easily absorbed; 3) hydralazine has a bioavallabllity of 30-50\% which can be increased If given simultaneously with solld food; 4) the area of action appears to be only on smooth muscle with no direct cardiac effects or effects on regulatory systems (40). Other potential vasodilators include captopril, prazosin, phentolamine, and nitroprusside. These drugs were not used because of their potential effects on cardiac muscle directly, on complex interaction with renal function, and/or the autonomic nervous system. Additionally, side effects associated with these drugs may have complicated the investigation. 
Subacute hemodynamic measurements were used for this study rather than chronic measurements. This helped to insure that animals were free from infection at the time of study and also insured a high percentage of catheter patency. Furthermore, this laboratory has demonstrated that subacute hemodynamics following ketamine/xylazine anesthesia accurately reflects chronic hemodynamics in the guinea pig (44).

In vitro passlve pressure volume curves were used to eval uate left ventricular chamber size. It has been recognized that the in vitro pressure-volume relationship is only one of several factors that determines pressure-volume relations in vivo (6). Other factors include restraint caused by simultaneous right ventricular pressure (47), the percardium (46), and coronary artery pressure (48). Despite these additional influences, the left ventricular pressure-volume relationship is a primary determinant of left ventricular chamber size In vivo.

The thermodllution method of determining cardlac output was utilized in this study. We feit justifled in using this method as it has been validated directly in our laboratory by simultaneous comparison with aortic flow in the guinea plg. Other potential options for determining cardlac output in small animals include the Fick method and the microsphere indicator dilution technique. The Fick method would require pulmonary artery catheterization and the additional restraint of the animal in a sealed chamber while attempting to measure resting hemodynamics. The use of microspheres requires handling of radioactive isotopes which are costly and require 
special disposal. In addition, multiple cardlac output determinations within a single animal require multiple labels. Thermodilution allows for repeated measurements in a single animal easily and reproducibly. Hydralazine was used to increase the diameter of the resistance vessels $(49,50,51)$. A larger vessel provides less resistance and permits more flow:

$$
Q=\frac{\Delta P \pi R^{4}}{8 \pi \ell}
$$

where $\Delta P=$ the change in pressure along a vessel, $R=$ the radius of the vessel, $\eta=$ the viscosity of the fluid, and $l=$ the length of the vessel. Systemic vascular resistance is calculated using a hemodynamic adaptation of Ohm's law from the formula: $R=\operatorname{map}-r a p / C 0$, where map is mean arterial pressure, rap is right atrial pressure, and $C 0$ is cardiac output. Units are in Pru's (peripheral resistance units) or Wood units. A change in systemic vascular resistance would be indirectly shown by an increase in cardlac output and/or a decrease In mean arterial pressure. During prelliminary dosing studies it was possible to monitor blood pressure for up to two weeks. The fact that blood pressure was generally decreased indicated that systemic vascular resistance was probably being decreased also (there was no reason to expect that cardiac output would have decreased).

The difficulties of maintalning a decreased systemic vascular resistance for three weeks may have been a result of hemodynamic compensation. The effects of vasodilation, in particular decreased blood pressure, can be countered by many physiologic mechanisms. The two major categories of blood pressure control mechanisms are short and long term regulation. 
One of the primary short-term blood pressure control mechanisms is the baroceptors. Baroreceptor (pressor) reflexes, which sense a drop in pressure, decrease inhibitory impulses to the vasoconstriction center and stop excitation of the vagal center. Chemoreceptors responding to increased carbon dioxide molecules and hydrogen ions, and to decreased oxygen avallability (due to decreased flow) excite nerve fibers leading to the vasomotor center. The final response is the same as that of the baroreceptors. Diminished blood flow due to acute vasodllation may also cause an ischemla in the brain eliciting a direct excitation of the vasomotor center. This causes a strong sympathetic response resulting in systemic vasoconstriction. Although this ischemia mechanism is usually augmented only in severe pressure loss situations, it is very powerful.

In addition to rapidly acting nervous mechanisms for blood pressure control, there are several hormonal mechanisms that also provide acute or subacute compensation. Sympathetic stimulation resulting from the above mechanisms causes release of epinephrine and norepinephrine from the adrenal medulla into the circulation. The increased adenergic activity stimulates beta receptors to increase heart rate and contractllity. Alpha receptors are stimulated to produce vasoconstriction in the arteries and veins.

Reduced arterial pressure stimulates the release of renin by the juxtagiomerular cells of the kidneys, thus producing angiotensin 1 and 11. Anglotensin 11 is a powerful vasoconstrictor and acts acutely on the arterioles and venuoles. In addition to the nervous and hormonal mechanisms, two other physical mechanisms of the circulation help to 
directly alter blood pressure. These mechanisms are the capillary fluid shift and the vascular stress relaxation mechanisms.

Many of these mechanisms may have contributed to compensation against the effects of hydralazine in this study. Short term mechanisms in general, however, lose their abillity to control blood pressure after a few hours to a few days. This is because the nervous pressure receptors lose their responsiveness and adapt. During the dose study the treated animals had lower blood pressures for up to two weeks. This would seem to indicate that the hydralazine given was effective enough to decrease blood pressure in spite of short term compensatory mechanisms.

A drop in arterlal pressure greatly decreases the rate at which the kidneys excrete water and salt. This is the result of the renalbody fluid mechanism. This long term mechanism is complex and not completely understood. Briefly, it controls blood pressure primarily via blood volume. A decrease in pressure causes the kidneys to decrease the output of water and salt. In addition to this pressure (diuresis and natriuresis), the low pressure causes increased secretion of renin by the kidneys, increased aldosterone secretion by the adrenal cortices, and increased sympathetic signals to the kidneys. All these in turn decrease the renal output of water and salt by varlous submechanisms.

In this study plasma volume was only increased by $2 \mathrm{ml}$ and was not statistically significant in the treated animals. However, it has been shown that a two percent increase in blood volume can increase the mean circulatory fllling pressure by five percent (52). An 
increase in cardiac output of five percent can increase systemic vascular resistance $25-50 \%$. These figures suggest that a two percent increase in blood volume may increase arterial pressure 30-57\%. A small increase in blood volume may therefore have been enough to cause blood pressure to stay near normal in the hydralazine treated animals. Of the many mechanisms that work to regulate blood pressure directly and systemlc vascular resistance indirectly, only one was the focus of this study: that of local vasomotion. It is possible that compensatory mechanisms such as the renal fluld-body and reninangiotensin mechanisms were engaged to such a degree that treated animal hemodynamics remained in normal ranges. One way to further address this problem would be to manipulate more than one hemodynamic control mechanism at a time. For example, a future study could vasodilate locally as in this study and at the same time inhibit angiotensin with a drug such as captopril. Then a portion of both the long and short term control systems would be affected.

This study was unable to provide conclusive evidence that systemic vascular resistance is a signal for heart size. The primary difficulties experienced seemed to stem from an inability to maintain a decreased systemic vascular resistance. The hypothesized results appeared in the form of trends all in the expected directions (increased cardiac output, left ventricular chamber size, and stroke volume), but were not statistically significant. In order to study the effects of systemic vascular resistance on heart size, future studies may have to direct efforts of controlling more than one hemodynamic control mechanism. This could be accomplished with multiple drugs administered simultaneously. 


\section{REFERENCES}

1. Longo, L. D. Maternal blood volume and cardlac output during pregnancy: A hypothesis of endocrinologic control. Am. J. Physiol. 245:R720-R729, 1983.

2. Ueland, K., Novy, M. J., Peterson, E. N., and Metcalfe, J. Maternal cardiovascular dynamics. Am. J. Obstet. Gynecol. $104: 856-864,1969$.

3. Myers, S. A., and Tseng, H. A longitudinal study of cardlac output in unstressed pregnant guinea pigs. Am. J. Physiol. 248:R698-R701, 1985.

4. Hoversland, A. S., Parer, S. T., and Metcalfe, J. Hemodynamic adjustments in the pygmy goat during pregnancy and early puerperla. Blol. Reprod. 10:578-588, 1974.

5. Lees, M. M., HIII, J. D., Ochsner, A. J., Thomas, C. I., and Novy, M. J. Maternal placental and myometrial blood flow of the rhesus monkey during uterine contractions. Am. J. Obstet. Gynecol. 110:68-81, 1971.

6. Rosenfeld, C. R. Distribution of cardiac output in ovine pregnancy. Am. J. Physlol. 232:H231-H235, 1977.

7. Barcroft, J., Kennedy, J. A., and Mason, M. F. The blood vol ume and kindred properties in pregnant sheep. J. Physiol. 95:159$172,1939$.

8. Hytten, F. E., and Paintin, D. B. Increase in plasma volume during normal pregnancy. J. Obstet. Gynecol. (B.C.) 70:402-407, 1963 
9. Pritchard, J. A. Changes in blood volume during pregnancy and delivery. Anesthesiology 26:393-399, 1965.

10. Burggraf, G. W., and Parker, J. O. Effects of dextran infusion on left ventricular volume in man. Cathet. Cardiovasc. Diag. $4: 383,1978$

11. Sanghul, V. R., Mark, A. L., Khuja, F., and Parker, J. 0. Effects of blood volume expansion on left ventricular hemodynamics In man. CIrculation 46:780-787, 1972.

12. Bader, R. A., Bader, M. E., Rose, D. J., and Braunwald, E. Hemodynamics at rest and during exercise In normal pregnancy as studied by cardiac catheterization. J. Clin. Invest. 34:1524$1536,1955$.

13. Hart, M. V., Hosenpud, J. D., Hoh Imer, A. R., and Morton, M. J. Hemodynamics during pregnancy and sex steroid administration in guinea plgs. Am. J. Physiol. 249:R179-R185, 1985.

14. Rubler, S., Schneebaum, R., and Hammer, N. Systollc time intervals in pregnancy and the postpartum period. Am. Heart $\mathrm{J}$. $86: 182-188,1973$.

15. Burg, J. R., Dodek, A., Kloster, F. E., and Metcalfe, J. Alterations of systollc time intervals during pregnancy. Circulation $47: 560-564,1974$.

16. Katz, R., Karliner, J. S., and Resnick, R. Effects of a natural volume overload state (pregnancy) on left ventricular performance in normal human subjects. Circulation 58:434-441, 1978. 
17. Mahler, F., Ross, J., O'Rourke, R. A., and Covell, J. W. Effects of changes in preload, afterload, and inotropic state on ejection and Isovolumic phase measurements of contractillity in the conscious dog. Am. J. Cardlol. 35:626-634, 1975.

18. MIInor. W. R. Arterlal impedance as ventricular afterload. Clrc. Res. 36:565-570, 1975.

19. Macdonald, A. The Bearings of Chronlc Disease of the Heart on Pregnancy, Parturition and Chlldbed with Papers on Puerperal Plueral Pneumonia and Eclampsla. London: J. \& A. Churchlll, 1878.

20. Morganroth, J., Maron, B. J., Henry, W. L., and Epstein, S. E. Comparatlve left ventricular dimensions in trained athletes. Ann. Intern. Med. 82:521-524, 1975.

21. Ross, J., Jr. Adaptations of the left ventricle to chronlc vol ume overload. Circ. Res. 34/35:11-64-11-70, 1974.

22. Burwell, C. S. The placenta as a modifled arterlovenous fistula, considered in relation to the circulatory adjustments to pregnancy. Am. J. Med. Scl. 195:1-7, 1938.

23. McCullagh, W. H., Covell, J. W., and Ross, J., Jr. Left ventricular dilatation and diastollc compliance changes during chronic volume overloading. Circulation 45:943-951, 1972.

24. Ueland, K., and Parer, J. T. Effects of estrogen on the cardlovascular system of the ewe. Am. J. Obstet. Gynecol. $96: 400-406,1966$.

25. Metcalfe, J., and Parer, J. T. Cardlovascular changes during pregnancy in ewes. Am. J. Physiol. 210:821-825, 1966. 
26. Walters, W. A. W., and LIm, Y. L. Haemodynamic changes in women taking oral contraceptives, J. Obstet. Gynecol. (B.C.) 77:1007$1012,1970$.

27. Walters, W. A. W., and LIm, Y. L. Cardiovascular dynamics in women recelving oral contraceptive therapy. Lancet 2:879-881, 1969.

28. Lehtovirta, P. Hemodynamic effects of combined estrogen/progesterone oral contraceptives. J. Obstet. Gynecol. (B.C.) $81: 517-525,1974$.

29. Mall now, M. R., Mogulevsky, J. A., Lema, B., and Bur, G. E. Vascular and extravascular radloactivity after injection of estradiol in the human belng. J. Clin. Endocrinol. Metab. $23: 306-310,1963$

30. MCGIII, H. C., and Sheridan, P. J. Nuclear uptake of sex hormones in the cardiovascular system of the baboon. Circ. Res. $48: 238-244,1981$

31. MCGIII, H. C., Anselmo, V. C., Buchanan, J. M., and Sheridan, P. J. The heart is a target organ for androgens. Science 207:775777,1980

32. Stumpf, W. E., Sar, M., and Aumuller, G. The heart: A target organ for estradiol. Sclence 196:319-321, 1977.

33. Ancill, R. J. The blood volume of the normal guinea-pig. J. Physlol. 132:469-475, 1956.

34. Constable, B. J. Estimation of Evans blue dye in blood plasma and its application to blood volume determination. Clin. Sci. $17: 597-602,1958$. 
35. Constable, B. J. Changes in blood vol ume and blood plcture during the llfe of the rat and guinea-pig from birth to maturity. J. Physiol. 167:229-238, 1963.

36. Challis, J. R. G., Heap, R. B., and IIllingworth, D. V. Concentrations of oestrogen and progesterone in the plasma of nonpregnant, pregnant and lactating guinea-pigs. J. Endocrinol. $51: 333-345,1971$.

37. Kunzel, W., and Moll, W. Uterine $\mathrm{O}_{2}$ consumption and blood flow of the pregnant uterus. Z. Geburtsh. Perinat. 176:108-116, 1972.

38. Hosenpud, J. D., Campbell, S. M., Hart, M. V., Paul, M. S., Rowles, J. R., and Niles, N. S. Experimental autolmmune myocarditis in the guinea pig. Cardlovasc. Res., in press, 1986

39. Morton, M., Tsang, H., Hohimer, R., Ross, D., Thornburg, K., Faber, J., and Metcalfe, J. Left ventricular slze, output, and structure during gulnea pig pregnancy. Am. J. Physlol. 246:R40R48, 1984

40. GIIman, A. G., Goodman, L., and GIIman, A. The Pharmacological Basis of Therapeutics, 6th ed. New York: Macmillan Publishing Co., 1980 , pp. $799-800$

41. Pegram, B. L., Ishise, S., and Frohlich, E. D. Effect of methyldopa, cionidine, and hydralazine on cardlac mass and haemodynamics in WIstar Kyoto and spontaneously hypertensive rats. Cardlovasc. Res. 16:40-46, 1982.

42. Chatterjee, K., Parmley, W. W., Massle, B., Greenberg, B., Werner, J., Klausner, S., and Norman, A. Oral hydralazine 
therapy for chronic refractory heart fallure. Circulation $54: 879-883,1976$

43. Frels, E. D., Rose, J. C., Higgins, T. F., Finnerty, F. A., Jr., Kelley, R. T., and Partenope, E. A. The hemodynamlc effects of hypotensive drugs in man. IV. 1-Hydrazinophthalazine. Circulation 8:199-204, 1953

44. Hart, M. V., Rowles, J. R., Hoh imer, A. R., Morton, M. J., and Hosenpud, J. D. Hemodynamics in the guinea pig after anesthetization with ketamine/xylazine. Am. J. Vet. Res. $45: 2328-2330,1984$.

45. Ganz, W., and Swan, H. J. C. Measurement of blood flow by thermodilution. Am. J. Cardiol. 29:241-246, 1972.

46. Glantz, S. A., and Parmley, W. W. Factors whlch af fect the diastol lc pressure-vol ume curve. Clrc. Res. 42:171-180, 1978.

47. Elzinga, G., van Grondelle, R., Westerhof, N., and van der Bos, G. C. Ventricular interference. Am. J. Physlol. 226:941-947, 1974.

48. Gaasch, W. H., Cole, J. S., PIne, M. A., Franklin, A., Clement, J., Rodes, D., Phear, W. P., and Wel ntraub, R. M. Myocardial contracture during prolonged ischemlc arrest and reperfusion. Am. J. Physlol. 235:H619-H627, 1978.

49. Stelnhard, A., Wortheimer, L., and Redisch, W. Studles on hydralazine: Evidence for a peripheral site of action. J. Clin. Invest. 33:1047-1053, 1954. 
33

50. Khatrl, 1., Uemuro, N., Notaglacomo, A., and Freis, E. D. Direct reflex cardlostimulating effects of hydralazine. Am. J. Cardiol. 40:38-42, 1977.

51. Koch-Weser, J. Myocardial Inactivity of therapeutic concentrations of hydralazine and diazoxide. Experientla $30: 170-171,1974$.

52. Guyton, A. C. Textbook of Medical Physiology, 6th ed. Philladel phla: W. B. Saunders Co., 1981, pp. 260-261. 